Guthöhrlein, G., \& Knappe, J. (1969) Eur. J. Biochem. 8, 207.

Jones, M. E. (1976) in The Urea Cycle (Grisolia, S., Baguena,

R., \& Mayor, F., Eds.) p 107, Wiley, New York.

Jones, M. E., \& Spector, L. (1960) J. Biol. Chem. 235, 2897.

Lowe, G., \& Sproat, B. S. (1978) J. Chem. Soc., Perkin Trans. 1,1622 .

Lowe, G., \& Sproat, B. S. (1980) J. Biol. Chem. 255, 3944.

Lowe, G., \& Sproat, B. S. (1981) J. Chem. Phys., Perkin Trans. 1 (in press).

Marshall, M., Metzenberg, R. L., \& Cohen, P. P. (1958) J. Biol. Chem. 233, 102.

Meister, A., \& Powers, S. G. (1978) Adv. Enzyme Regul. 16, 289.
Metzenberg, R. L., Marshall, M., \& Cohen, P. P. (1958) J. Biol. Chem. 233, 1560.

Midelfort, C. F., \& Rose, I. A. (1976) J. Biol. Chem. 251, 5881.

Raushel, F. M., \& Villafranca, J. J. (1979) Biochemistry 18, 3424.

Rubio, V., \& Grisolia, S. (1977) Biochemistry 16, 321.

Rubio, V., Britton, H. G., \& Grisolia, S. (1979) Eur. J. Biochem. 93, 245.

Sauers, C. K., Jencks, P. J., \& Groh, S. (1975) J. Am. Chem. Soc. 97, 5546.

Wimmer, M. J., Rose, I. A., Powers, S. G., \& Meister, A. (1979) J. Biol. Chem. 254, 1854.

\title{
Phospholipid Asymmetry in Semliki Forest Virus Grown on Baby Hamster Kidney (BHK-21) Cells ${ }^{\dagger}$
}

\author{
Gerrit van Meer,* Kai Simons, Jos A. F. Op den Kamp, and Laurens L. M. van Deenen
}

ABSTRACT: The distribution of the different phospholipid classes over the two leaflets of the membrane of Semliki Forest virus, grown on baby hamster kidney cells (BHK-21), was studied. To localize the phospholipids we have used a phosphatidylcholine-specific exchange protein, a nonspecific exchange protein, phospholipases $\mathrm{A}_{2}$ and $\mathrm{C}$, sphingomyelinase, and the amino group labeling reagent trinitrobenzenesulfonate. When low concentrations of exchange proteins and phospholipases were used, only those phospholipids present in lysed or otherwise defective virions were detected. Up to $10 \%$ of the phospholipids are present in such particles, and this amount correlated well with the amount of ribonuclease-degradable RNA present in each virus preparation. In the actual localization experiments, carried out with higher concentrations of exchange proteins and phospholipases as well as with trinitrobenzenesulfonate, the various independent techniques yielded identical results. The outer membrane layer of the virus contains $52 \%$ of the phosphatidylcholine, $22 \%$ of the phosphatidylethanolamine, and $33 \%$ of the sphingomyelin. Phosphatidylserine could not be localized. Altogether $30 \%$ of the total phospholipids could be assigned to the outer layer and $50 \%$ to the inner membrane leaflet whereas $20 \%$ could not be localized. Calculations, based on the size of the Semliki Forest virus and the number of phospholipid molecules per virion, indicate it to be unlikely that the phospholipids which could not be localized are present in the inner bilayer leaflet. The present data on phospholipid composition and distribution have been compared with previous results on the lipid distribution in plasma membrane derived structures. It is concluded that an asymmetric distribution of phospholipids in the plasma membrane of various mammalian cells is apparent.

gano, 1978). Right side out derivatives of the plasma membrane can be studied by means of enveloped viruses which obtain their lipid constituents from the host cell plasma membrane during budding [for a review, see Patzer et al. (1979)]. The lipid composition of these viruses strongly resembles the lipid composition of the host cell plasma membrane. Extensive studies have been carried out with influenza virus (Tsai \& Lenard, 1975; Rothman et al., 1976; Lenard \& Rothman, 1976) and vesicular stomatitis virus (Patzer et al., 1978a,b; Shaw et al., 1979; Fong et al., 1976; Fong \& Brown, 1978), which show that the phospholipids are distributed in an asymmetric way over the two halves of the virus membranes.

Also, Semliki Forest virus buds through the plasma membrane of the host cell (Acheson \& Tamm, 1967; Richardson

\footnotetext{
${ }^{1}$ Abbreviations used: SF virus, Semliki Forest virus; BHK-21, a baby hamster kidney cell line; LM, a fibroblast cell line; MDBK, Maden Darby bovine kidney; EDTA, ethylenediaminetetraacetic acid; TN, buffer containing $100 \mathrm{mM} \mathrm{NaCl}$ and $50 \mathrm{mM}$ tris(hydroxymethyl)aminomethane, $\mathrm{pH} 7.4$, with $\mathrm{HCl}$; TNBS, 2,4,6-trinitrobenzenesulfonate; PC, phosphatidylcholine; PE, phosphatidylethanolamine; PS, phosphatidylserine; SM, sphingomyelin; PI, phosphatidylinositol; $\mathrm{NaDodSO}_{4}$, sodium dodecyl sulfate.
} 
\& Vance, 1976) and has a lipid composition which closely resembles that of the host cell (Renkonen et al., 1971; Laine et al., 1972). In this study we report on the asymmetric phospholipid distribution in Semliki Forest virus grown in BHK-21 cells and show that this asymmetry is similar to the asymmetry found in vesicular stomatitis virus grown in the same type of host cell (Patzer et al., 1978a,b; Shaw et al., 1979; Fong et al., 1976; Fong \& Brown, 1978).

\section{Materials and Methods}

Growth and Purification of the Virus. A prototype strain of Semliki Forest virus was grown in confluent monolayer cultures of BHK-21 cells and purified by gradient centrifugation as described by Kääriäinen et al. (1969). The virus was used immediately or stored at $-80^{\circ} \mathrm{C}$. After being thawed, the virus was never frozen for a second time. Cells were grown and virus infection was carried out in Eagle's minimum essential medium containing $0.1 \mathrm{mM}$ instead of the usual $1 \mathrm{mM}$ phosphate to obtain ${ }^{32} \mathrm{P}$-labeled SF virus. [ $\left.{ }^{32} \mathrm{P}\right]$ Orthophosphate (Amersham Buchler) was added to the medium at a specific activity of $80 \mu \mathrm{Ci} / \mathrm{mL}$ (Helenius et al., 1977). The cells were grown in this medium for two passages (Renkonen et al., 1972) to obtain uniformly labeled phospholipids. After this procedure, the label appeared to be uniformly distributed (Table I). The isotope was added to the medium after infection at a final concentration of $0.1 \mathrm{mCi} / \mathrm{mL}$ culture medium for labeling with $\left[{ }^{3} \mathrm{H}\right]$ uridine (Amersham Buchler). Spikeless particles were prepared and purified as described by Utermann \& Simons (1974) by digestion of the protein spikes with thermolysin. The spikeless particles banded at a density of $1.15 \mathrm{~g} / \mathrm{cm}^{3}$ in sucrose gradient centrifugation, while intact virus banded at $1.19 \mathrm{~g} / \mathrm{cm}^{3}$. For the calculation of the phospholipid content of the different preparations, the composition of the virus as given by Laine et al. (1973) was used and protein was determined by the Lowry et al. (1951) method with $3.5 \mathrm{mM} \mathrm{NaDodSO}{ }_{4}$ in the reaction mixture.

Phospholipase Incubations. Phospholipase C (EC 3.1.4.3) from Bacillus cereus was purified according to Zwaal et al. (1971). The enzyme was stored in 50\% (v/v) glycerol at -20 ${ }^{\circ} \mathrm{C}$ at a concentration of $0.65 \mathrm{IU} / \mu \mathrm{L}$. SF virus was incubated in TN buffer containing $5 \mathrm{mM} \mathrm{Ca}^{2+}$ and $0.25 \mathrm{mM} \mathrm{Mg}^{2+}$, with phospholipase $C$ at a final concentration of $100-300 \mathrm{IU} / \mathrm{mL}$ at 25 and $37^{\circ} \mathrm{C}$. The hydrolysis was stopped by addition of a sample to an equal volume of water containing $0.2 \mathrm{M}$ EDTA and $0.1 \mathrm{M} \mathrm{1,10-phenanthrolinium} \mathrm{chloride.} \mathrm{The} \mathrm{procedure}$ of Colley et al. (1973) was used to purify sphingomyelinase (EC 3.1.4.12) from Staphylococcus aureus, and it was stored as phospholipase $C$ at a concentration of $0.23 \mathrm{IU} / \mu \mathrm{L}$. SF virus was incubated with $25-50 \mathrm{IU} / \mathrm{mL}$ sphingomyelinase in TN buffer containing $10 \mathrm{mM}$ of $\mathrm{Ca}^{2+}$ at 20,25 , and $37^{\circ} \mathrm{C}$. Hydrolysis was stopped by the addition of a sample to an equal volume of $0.2 \mathrm{M}$ EDTA. Time curves were made over total periods of $1.5 \mathrm{~h}$.

Phospholipase $\mathrm{A}_{2}$ (EC 3.1.1.4) from pig pancreas was prepared according to Nieuwenhuizen et al. (1974) and stored as phospholipase $\mathrm{C}$ but at a concentration of $1 \mathrm{IU} / \mu \mathrm{L}$. Virions were incubated in TN buffer containing $10 \mathrm{mM} \mathrm{Ca}^{2+}$ and 0.25 $\mathrm{mM} \mathrm{Mg}^{2+}$ with $100-200 \mathrm{IU} / \mathrm{mL}$ phospholipase $\mathrm{A}_{2}$ at 10,20 , and $37^{\circ} \mathrm{C}$. The reaction was ended as in sphingomyelinase incubations. Hydrolysis was followed during $2 \mathrm{~h}$.

Labeling with TNBS, 2,4,6-Trinitrobenzenesulfonate (TNBS) was purchased from Sigma Chemical Co. A $40 \mathrm{mM}$ solution of TNBS in $10 \mathrm{mM}$ phosphate buffer, $\mathrm{pH} 8.0$, was prepared fresh each time. Virus was incubated in $10-40 \mathrm{mM}$ TNBS at 20,25 , and $37^{\circ} \mathrm{C}$ during $3 \mathrm{~h}$ at most. At appropriate times labeling was stopped by adding a sample to an equal volume of $0.2 \mathrm{M}$ acetic acid. Controls treated this way did not show any labeling of PE.

Phosphatidylcholine Exchange between Virus and Liposomes. A PC-specific exchange protein was purified from beef liver as described by Kamp \& Wirtz (1974). The exchange protein was stored at $-20^{\circ} \mathrm{C}$ in $50 \%(\mathrm{v} / \mathrm{v})$ glycerol. After dialysis against TN buffer immediately before use, the exchange protein was concentrated to a final concentration of $200 \mu \mathrm{g} / \mathrm{mL}$ against Ficoll. Hand-shaken multilamellar vesicles were freshly prepared from egg PC, $10 \% \mathrm{egg} \mathrm{PA}$, and a trace of $\left[{ }^{14} \mathrm{C}\right]$ cholesteryl oleate, essentially as described by Bangham et al. (1965) in TN buffer. After $1 \mathrm{~h}$ at room temperature they were centrifuged at $20000 \mathrm{~g}$ for $30 \mathrm{~min}$. The sedimented multilamellar vesicles were gently resuspended in buffer, to a concentration of $10 \mu \mathrm{mol}$ of $\mathrm{PC} / \mathrm{mL}$. Unilamellar vesicles were freshly prepared by sonicating the multilamellar vesicle suspension for 10 min at $4{ }^{\circ} \mathrm{C}$ under nitrogen by using a Branson sonifier (output $70 \mathrm{~W}$ ) and centrifugation at $100000 \mathrm{~g}$ for $45 \mathrm{~min}$. The concentration of vesicle $P C$ was 7-8 $\mu \mathrm{mol} / \mathrm{mL}$. In some experiments unilamellar vesicles containing $50 \mathrm{~mol} \%$ cholesterol were used as the acceptor.

Unless otherwise stated $\left.{ }^{32} \mathrm{P}\right] \mathrm{SF}$ virus $(5-10 \mathrm{nmol}$ of phospholipid phosphorus) was incubated at $37^{\circ} \mathrm{C}$ with unilamellar vesicles ( $200 \mathrm{nmol}$ of $\mathrm{PC}$ ) and exchange protein in a final volume of $0.6 \mathrm{~mL}$. The final exchange protein concentration was $0-150 \mu \mathrm{g} / \mathrm{mL}$. In control incubations, either the exchange protein or the vesicles and exchange protein were omitted. Exchange was stopped after 1,2, 3, or $4 \mathrm{~h}$ by dilution of a 100- $\mu \mathrm{L}$ sample with $1 \mathrm{~mL}$ of ice-cold buffer. This mixture was then immediately put on top of $10 \mathrm{~mL}$ of $10 \%$ sucrose and spun for $2 \mathrm{~h}$ at $100000 \mathrm{~g}$. The supernatant was discarded and the pellet used for further analysis.

Phospholipid Transfer between Virus and Vesicles. A partly purified phospholipid universal transfer protein was prepared according to Bloj \& Zilversmit (1977). Phospholipid vesicles were prepared by sonicating $1 \mu \mathrm{mol}$ of bovine brain $\mathrm{SM}, 2 \mu \mathrm{mol}$ of egg PC, and $3 \mu \mathrm{mol}$ of egg PE in $1 \mathrm{~mL}$ of TN buffer as described for PC vesicles. In two other experiments ratios of SM:PC:PE $=1: 1: 1$ or 1:3:3 were used. Routinely $\left.{ }^{32} \mathrm{P}\right] \mathrm{SF}$ virus was incubated with vesicles as described for the exchange protein but this time with a final concentration of 0-300 $\mu \mathrm{g}$ of transfer protein $/ \mathrm{mL}$. Transfer was stopped after $1,2,3,4$, or $5 \mathrm{~h}$ as described for the exchange protein incubations. The virus pellet was used to further analysis.

Analysis of Phospholipids. All samples were diluted to 0.5 $\mathrm{mL}$ with distilled water and extracted by using the procedure of Bligh \& Dyer (1959). Chloroform and methanol were obtained from Baker Chemicals. In extractions of $\left[{ }^{32} \mathrm{P}\right] \mathrm{SF}$ virus, carrier lipid ( $300 \mathrm{nmol}$ of phospholipid phosphorus, extracted from pig erythrocytes) was added to the one-phase system. After incubations of [ $\left.{ }^{32} \mathrm{P}\right] \mathrm{SF}$ virus with phospholipase $\mathrm{A}_{2}$ or TNBS, unlabeled lysophospholipids or trinitrophenyl-PE were added to the carrier lipid. The lower organic phase was dried under a stream of nitrogen. The residue was dissolved in a minimal volume of chloroform-methanol $(2: 1 \mathrm{v} / \mathrm{v})$ and spotted onto nonactivated precoated TLC plates (Merck Kieselgel 60 DC-Fertigplatten). The plates were developed by using the system of Broekhuyse (1969) adapted for precoated TLC plates. As the first solvent chloroform-methanol-25\% ammonia-water $(90: 54: 5.7: 5.3 \mathrm{v} / \mathrm{v} / \mathrm{v} / \mathrm{v})$ was used, and in the second direction chloroform-methanol-acetic acid-water $(90: 30: 8: 2.85 \mathrm{v} / \mathrm{v} / \mathrm{v} / \mathrm{v})$ was used. In between the runs, the plates were dried for $15 \mathrm{~min}$ under a hot hair dryer. By use of this system a good separation between all phospholipids, lysophospholipids, and trinitrophenyl-PE was ob- 
tained. Only PI was not separated from PS, but PI is a minor phospholipid in the SF virus membrane, accounting for $1 \%$ of the total phospholipids only (Renkonen et al., 1971). The phospholipid spots were visualized by staining with $\mathrm{I}_{2}$ and scraped off after evaporation of the $\mathrm{I}_{2}$. ${ }^{32} \mathrm{P}$-Labeled phospholipids were counted in a Packard liquid scintillation counter by using a toluene scintillation fluid containing PPO $(0.5 \%$ $\mathrm{w} / \mathrm{v})$, dimethyl-POPOP $(0.025 \% \mathrm{w} / \mathrm{v})$, and Biosolve $(2 \% \mathrm{v} / \mathrm{v}$, Beckman Instruments, Inc.) as a solubilizer. Phosphate in unlabeled phospholipids was determined according to Rouser et al. (1970).

Measurements of Phospholipid Hydrolysis and Exchange. Phospholipid hydrolysis by phospholipase $\mathrm{A}_{2}$ could be quantitated as the loss of PC, PS, and PE by using SM as a nondegradable standard. The same results were obtained when the sum of all phospholipids minus PS was taken as a standard, indicating that in contrast to the water-soluble lysoPS, no lyso-PC and lyso-PE were lost in the water phase of the extraction. Hydrolysis of phospholipids by phospholipase $\mathrm{C}$ was quantitated in two ways. SM was used as a standard, or the loss of PC, PS, and PE was derived immediately from the absolute amounts of these phospholipids in the different time samples. The two methods were in good agreement. SM degradation by sphingomyelinase was determined by using the sum of the other phospholipid classes as a standard. The reaction of PE with TNBS was calculated from the loss of PE or the formation of trinitrophenyl-PE by using the sum of all phospholipids as a standard. The two determinations gave equal results. Exchange of $\mathrm{PC}$ was calculated as the loss of $\left[{ }^{32} \mathrm{P}\right] \mathrm{PC}$ compared to the $\left[{ }^{32} \mathrm{P}\right] \mathrm{SM}$ or the sum of $\left[{ }^{32} \mathrm{P}\right] \mathrm{SM}, \mathrm{PS}$, and $\mathrm{PE}$ as a standard. In the case of phospholipid transfer by the transfer protein, calculations could only be made based on absolute quantities of the different phospholipid classes in the different time samples, because all phospholipid classes can be transferred by this protein (Bloj \& Zilversmit, 1977). Separation of SF virus from the vesicles in the exchange experiments was judged from ${ }^{14} \mathrm{C} /{ }^{32} \mathrm{P}$ double label counting of part of the virus pellet extract. For calculations only those points were used in which the difference between the duplicate determinations was smaller than $5 \%$.

Ribonuclease Digestions. To $50 \mu \mathrm{L}$ of a $\left[{ }^{3} \mathrm{H}\right]$ uridine-labeled SF virus preparation was added $10 \mu \mathrm{L}$ of a ribonuclease solution of $1 \mathrm{IU} / \mu \mathrm{L}$ (Boehringer, Mannheim). This mixture was diluted to $100 \mu \mathrm{L}$ with different solutions according to the different incubation conditions. After incubation for an appropriate time at 20 or $37^{\circ} \mathrm{C}, 400 \mu \mathrm{L}$ of $6 \%$ trichloroacetic acid was added at $0^{\circ} \mathrm{C}$ and the acid-soluble material precipitated at $20000 \mathrm{~g}$ for $30 \mathrm{~min}$. Radioactivity in the supernatant was determined.

\section{Results}

Phospholipid Composition of the Virus. The distribution of ${ }^{32} \mathrm{P}$ over the different phospholipid classes in uniformly labeled virus was compared to the phospholipid composition as measured by a phosphorus assay (Table I). This is important, because the virus is derived from the plasma membrane which is the last cellular membrane to equilibrate with ${ }^{32} \mathrm{P}$. A good correlation was obtained and therefore ${ }^{32} \mathrm{P}$-labeled virus was used in the localization experiments. The preparation of spikeless particles has no effect on the phospholipid composition (Table I).

Exchange of PC between Virus and Vesicles. A good separation between donor and acceptor membranes after the incubation is required in order to study the redistribution of [ $\left.{ }^{32} \mathrm{P}\right] \mathrm{PC}$ between SF virus and lipid vesicles. This separation was obtained by centrifugation in $10 \%$ sucrose. The extent
Table I: Phospholipid Composition and ${ }^{32} \mathrm{P}$ Distribution in Different SF Virus Preparations ${ }^{a}$

\begin{tabular}{lccc}
\hline & \multicolumn{3}{c}{ composition (\%) } \\
\cline { 2 - 4 } & $\begin{array}{c}\text { unlabeled } \\
\text { virus }\end{array}$ & $\begin{array}{c}\text { uniformly } \\
\text { labeled virus }\end{array}$ & $\begin{array}{c}\text { spikeless } \\
\text { particles }\end{array}$ \\
\hline SM & $23.7 \pm 0.9^{b}$ & $24.9 \pm 0.1$ & $24.1 \pm 0.5$ \\
PC & $28.9 \pm 1.6$ & $26.7 \pm 1.6$ & $29.0 \pm 1.1$ \\
PS & $17.3 \pm 1.2$ & $18.6 \pm 1.1$ & $18.2 \pm 0.6$ \\
PE & $24.5 \pm 1.4$ & $26.2 \pm 1.6$ & $23.6 \pm 0.4$ \\
\hline
\end{tabular}

${ }^{a}$ SF virus was grown, unlabeled or ${ }^{32} \mathrm{P}$ labeled, and purified. Spikeless particles were prepared from ${ }^{32} \mathrm{P}$-labeled virus. The lipids were analyzed by TLC and quantitated by phosphorus determination for the unlabeled virus $(n=8)$ or scintillation counting for the uniformly labeled virus $(n=4)$ and spikeless particles $(n=2)$, everything as described under Materials and Methods. ${ }^{b}$ Composition is expressed as percentage of total phospholipids. The remaining 5\% were not analyzed [cf. Renkonen et al. (1971)].

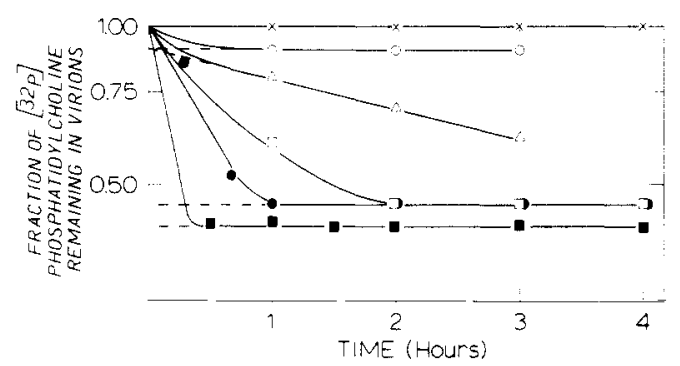

FIGURE 1: Semilogarithmic plot of the loss of [ $\left.{ }^{32} \mathrm{P}\right] \mathrm{PC}$ from [ $\left.{ }^{32} \mathrm{P}\right] \mathrm{SF}$ virus (5-10 nmol of phospholipid phosphorus) that had been incubated with $\mathrm{PC}$ vesicles, containing $10 \% \mathrm{PA}$, and different concentrations of $P C$ specific exchange protein in a final volume of $0.6 \mathrm{~mL}$ at 37 ${ }^{\circ} \mathrm{C}$. $250 \mathrm{nmol}$ of PC without exchange protein $(X) ; 1000 \mathrm{nmol}$ of $P C$ plus $40 \mu \mathrm{g} / \mathrm{mL}$ exchange protein (O); $250 \mathrm{nmol}$ of $\mathrm{PC}$ plus 50 $\mu \mathrm{g} / \mathrm{mL}$ exchange protein $(\Delta) ; 150 \mathrm{nmol}$ of $P C$ plus $120 \mu \mathrm{g} / \mathrm{mL}$ exchange protein (ם); $225 \mathrm{nmol}$ of PC plus $150 \mu \mathrm{g} / \mathrm{mL}$ exchange protein (); spikeless particles (from [ $\left.{ }^{32} \mathrm{P}\right] \mathrm{SF}$ virus; $5 \mathrm{nmol}$ of phospholipid phosphorus) plus $500 \mathrm{nmol}$ of PC plus $45 \mu \mathrm{g} / \mathrm{mL}$ exchange protein $(\boldsymbol{E})$. Samples were taken and analyzed as described under Materials and Methods. All symbols represent the mean of two independent determinations and are expressed as the fraction of total viral $\left[{ }^{32} \mathrm{P}\right] \mathrm{PC}$ at $t=0 \mathrm{~h}$. The difference between the two determinations was always less than $5 \%$. Identical data were obtained in five (O), five $(\Delta)$, three $(\square)$, three $(\bullet)$, and five $(\square)$ independent experiments.

of contamination of the resulting virus pellet with vesicles was determined by measuring the amount of $\left[{ }^{14} \mathrm{C}\right]$ cholesteryl oleate which was present as a nonexchangeable marker in the vesicles and appeared to be less than $2 \%(n=5)$. However, when cholesterol (50\%) was present in the lipid vesicles, contamination was high. Therefore, subsequent experiments were carried out with vesicles without cholesterol. In control incubations of virus with vesicles but without exchange protein, no or hardly any exchange of PC could be detected: $1.6 \pm$ $1.4 \%(n=3)$ of the total virus PC had been exchanged after $3 \mathrm{~h}$. When virus was incubated with vesicles in the presence of exchange protein, an exchange pattern was observed as shown in Figure 1. At low protein concentrations a small part of the PC is available for exchange only. Increasing the exchange protein concentration reveals a second pool of $\mathrm{PC}$ which is available for exchange. The maximal exchange of PC can be obtained with $150 \mu \mathrm{g}$ of protein $/ \mathrm{mL}$ within $1 \mathrm{~h}$. Further increase in the amount of protein or the use of a higher vesicle concentration do not cause additional PC exchange. When these data are presented in a semilogarithmic plot (Figure 1), it is obvious that the rate of exchange depends on the protein concentration and that $\mathrm{PC}$ is present in three different pools in the virus preparation. A small amount $(11.7 \pm 2.3 \%)$ is readily accessible; $54.3 \pm 2.8 \%$ of the total $P C$ is less accessible 
Table II: Phospholipid Pool in SF Virus That Is Readily Accessible for Low Concentrations of Exchange Proteins and Phospholipases

\begin{tabular}{|c|c|c|c|c|}
\hline \multirow[b]{2}{*}{ reaction } & \multicolumn{4}{|c|}{$\%$ of each phospholipid class hydrolyzable or exchangeable } \\
\hline & $\mathrm{PC}$ & SM & PS & $\mathrm{PE}$ \\
\hline 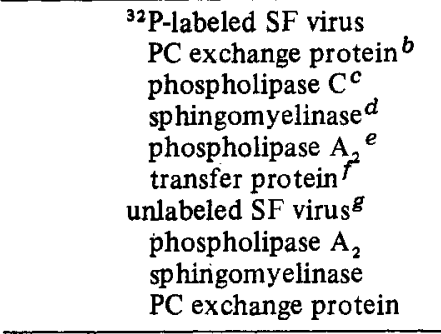 & $\begin{aligned} 11.7 & \pm 2.3(10)^{a} \\
15.0 & \pm 1.4(2) \\
11.3 & \pm 5.4(5) \\
9.9 & \pm 2.5(5) \\
6.5 & \pm 0.5(3) \\
12.5(1) & \end{aligned}$ & $\begin{array}{l}11.0 \pm 3.2(8) \\
10.0 \pm 3.3(4) \\
12.1 \pm 3.0(2)\end{array}$ & $8.5 \pm 2.1(2)$ & $\begin{aligned} 15.0 & \pm 1.3(2) \\
15.4 & \pm 7.9(5) \\
7.0 & \pm 0(2) \\
10.6 & \pm 2.5(3)\end{aligned}$ \\
\hline $\begin{array}{l}\text { The numbers represent the mear } \\
\text { the exchange protein in Figure } 1 \text { an } \\
\text { in parentheses. } b \text { SF virus was incu } \\
\text { protein } / \mathrm{mL} \text { and } 250 \text { nmol of PC (fi } \\
\text { readily accessible PC pool was deter } \\
\text { or } 150 \mathrm{IU} / \mathrm{mL} \text { phospholipase } \mathrm{C} \text { at } 2 \\
\text { virus was incubated with } 25 \text { or } 30 \mathrm{I} \\
\text { described under Materials and Meth } \\
\text { incubated with } 100 \mathrm{IU} / \mathrm{mL} \text { phospho } \\
\text { every } 20 \text { min, as described under M } \\
f \text { SF virus was incubated with } 200 \text { } \\
\text { sisting of SM:PC:PE }=1: 2: 3 \text { in the } \\
\text { tions were carried out at } 37^{\circ} \mathrm{C} \text { and } \\
\text { readily accessible pool of SM, PS, or } \\
\text { ments. } B \text { Incubations of unlabeled } \\
\text { extrapolation of the curves as descri }\end{array}$ & $\begin{array}{l}\text { tage (each of the } \\
\text { ospholipases in Fi } \\
\text { ith } 40 \mu \mathrm{g} \text { of excha } \\
\text { iments), and samp } \\
\text { om extrapolation } \\
\text { escribed under } \mathrm{M} \\
\text { hingomyelinase (f } \\
\text { le curves were ext } \\
\text { at } 10,15 \text {, and } 2 \\
\text { nd Methods. The } \\
/ \mathrm{mL} \text { transfer prot } \\
00 \mu \mathrm{g} / \mathrm{mL} \text { transfe } \\
\text { were taken every } \\
\text { ld not be determir } \\
\text { re performed as d } \\
\text { lated SF virus }\end{array}$ & $\begin{array}{l}\text { ercen tages is the } \\
\text { It is followed } b \\
\text { ein/mL and } 100 \\
\text { taken and analy } \\
\text { drves to } t=0 \text { as } \\
\text { d Methods. Th } \\
\text { riments each) at } \\
\text { to } t=0 \text { as is sh } \\
\text {, two, and one } \\
\text { vere extrapolate } \\
\text { e and two exper } \\
\text { and } 1: 1: 1 \text { or } 1: \\
\text { escribed under } \\
\text { ase of the lack o } \\
\text { under Results. }\end{array}$ & $\begin{array}{l}\text { of the extrapol } \\
\text { andard deviatio } \\
\text { of PC (five exp } \\
\text { as described un } \\
\text { in Figure } 1 . \\
\text { s were extrapo } \\
\text { and samples we } \\
\text { phospholipase } \\
\text { lents, respective } \\
0 \text { as is shown f } \\
\text { respectively) ir } \\
\text { he case of } 300 \\
s \text { and Methods. } \\
\text { correlation be }\end{array}$ & $\begin{array}{l}\text { a curve, as described for } \\
\text { he number of experiments } \\
\text { s) or } 50 \mu \mathrm{g} \text { of exchange } \\
\text { erials and Methods. The } \\
\text { was incubated with } 100 \\
\text { shown in Figure } 2 \text {. } \mathrm{SF} \\
\text { n every } 15 \mathrm{~min} \text {, as } \\
\text { gure } 2 \text {. e SF virus was } \\
1 \text { samples were taken } \\
\text { pholipase } \mathrm{C} \text { in Figure } 2 . \\
\text { esence of vesicles con- } \\
\text { ransfer protein. Incuba- } \\
\text { ne experiments the } \\
\text { he duplicate measure- } \\
\text { s determined by }\end{array}$ \\
\hline
\end{tabular}

Table III: Phospholipid Pool in SF Virus That Is Readily Accessible for TNBS and High Concentrations of Exchange Protein and Phospholipases

\begin{tabular}{|c|c|c|c|}
\hline \multirow[b]{2}{*}{ reaction } & \multicolumn{3}{|c|}{$\%$ of each phospholipid class accessible } \\
\hline & $\mathrm{PC}$ & SM & $\mathrm{PE}$ \\
\hline \multicolumn{4}{|l|}{$\begin{array}{l}\text { PC exchange } \\
\text { protein }\end{array}$} \\
\hline $\begin{array}{l}\text { intact virus }{ }^{b} \\
\text { spikeless } \\
\text { particles }\end{array}$ & $\begin{array}{l}54.3 \pm 2.8(6)^{a} \\
58.8 \pm 3.8(5)\end{array}$ & & \\
\hline $\begin{array}{l}\text { phospholipase } C^{d} \\
\text { sphingomyelinase }\end{array}$ & $53.2 \pm 5.5(4)$ & $39.7 \pm 9.4(4)$ & $28.8 \pm 0.5(3)$ \\
\hline $\begin{array}{l}\text { phospholipase } \mathrm{A}_{2} f \\
\text { TNBS }\end{array}$ & $57.0(1)$ & & $\begin{array}{l}20.0(1) \\
30.9 \pm 6.8(10)\end{array}$ \\
\hline
\end{tabular}

\footnotetext{
${ }^{a}$ The numbers represent the mean percentage (each of the original percentages is the result of the extrapolation of a curve, as described for the exchange protein in Figure 1, the phospholipases in Figure 2, and TNBS in Figure 3). It is followed by the standard deviation and the number of experiments in parentheses. $b$ SF virus was incubated with $120 \mu \mathrm{g}$ of exchange protein $/ \mathrm{mL}$ and $150 \mathrm{nmol}$ of PC or $150 \mu \mathrm{g}$ of exchange protein $/ \mathrm{mL}$ and $225 \mathrm{nmol}$ of PC (three experiments each) as described under Materials and Methods. The accessible PC pool was determined from extrapolation of the curves to $t=0$ as shown in Figure 1. ${ }^{c}$ SF virus was incubated with $20 \mu \mathrm{g}$ of exchange protein $/ \mathrm{mL}$ and $500 \mathrm{nmol}$ of PC (two experiments) or $45 \mu \mathrm{g}$ of exchange protein $/ \mathrm{mL}$ and $500 \mathrm{nmol}$ of PC (three experiments) as described under Materials and Methods for intact virus. Samples were taken every hour and the accessible PC pool was determined from extrapolation as shown in Figure 1. ${ }^{d} \mathrm{SF}$ virus was incubated with 200,250 , or $300 \mathrm{IU}$ of phospholipase $\mathrm{C} / \mathrm{mL}$ (two, one, or one experiment, respectively) at $25^{\circ} \mathrm{C}$ as described under Materials and Methods. The curves were extrapolated as is shown in Figure $2 .{ }^{e} \mathrm{SF}$ virus was incubated with 30,40 , or $50 \mathrm{IU}$ of sphingomyelinase $/ \mathrm{mL}$ (two, one, or one experiment, respectively) at $25^{\circ} \mathrm{C}$ and samples were taken every $15 \mathrm{~min}$, as described under Materials and Methods. The curves were extrapolated as shown in Figure 1 for phospholipase C. ${ }^{\mathrm{SF}} \mathrm{\text {virus}}$ was incubated with $200 \mathrm{IU}$ of phospholipase $\mathrm{A}_{2}$ at $20^{\circ} \mathrm{C}$ and samples were taken every $20 \mathrm{~min}$ as described under Materials and Methods. The curve was extrapolated as shown in Figure 1 for phospholipase C. $\mathrm{g}$ SF virus was incubated with 10 , 20 , or $30 \mathrm{mM}$ TNBS (six, two, and two experiments, respectively) at $20^{\circ} \mathrm{C}$ and samples were taken as described under Materials and Methods. The curves were extrapolated as shown in Figure 3.
}

but can be exchanged under favorable conditions (see also Tables II and III) and the residual PC is not accessible (see Discussion). For investigation of the possibility that the nonaccessible PC was shielded by the glycoprotein spikes, vesicles were incubated with spikeless particles and exchange protein. A total of $58.8 \pm 3.8 \%$ of the PC was available for exchange also at low concentrations of exchange protein $(20-45 \mu \mathrm{g} / \mathrm{mL})$. As with intact virions, addition of fresh exchange protein and/or vesicles had no influence on the extent of exchange in spikeless particles. It was furthermore controlled that the relative composition of the other phospholipid classes did not change during the experiments.

Hydrolysis of Phospholipids by Phospholipase C. When $\left.{ }^{32} \mathrm{P}\right] \mathrm{SF}$ virus was incubated with phospholipase $\mathrm{C}$ at different enzyme concentrations $(100-300 \mathrm{IU} / \mathrm{mL})$ and temperatures $\left(25\right.$ and $37^{\circ} \mathrm{C}$ ), with respect to $\mathrm{PC}$ and $\mathrm{PE}$ hydrolysis, similar phenomena were observed as with the exchange experiments. The results are shown in Figure 2. This semilogarithmic plot shows that PC is available for hydrolysis in three different pools. As long as the enzyme concentration is kept below 150 $\mathrm{IU} / \mathrm{mL}$ (at $25^{\circ} \mathrm{C}$ ), $15.0 \pm 1.4 \%$ of $\mathrm{PC}$ is hydrolyzed at a fast rate. The amount of this readily accessible $\mathrm{PC}$ is independent of enzyme concentrations under these conditions; only the rate of hydrolysis varies. At higher enzyme concentrations a biphasic hydrolysis pattern is observed. With 200, 250, and 300 IU of enzyme $/ \mathrm{mL}, 53.2 \pm 5.5 \%$ of the viral PC is readily hydrolyzed whereas the residual PC can only be hydrolyzed at a much lower rate. For PE hydrolysis, curves were found and extrapolations made, similar to those shown in Figure 2: $15.0 \pm 1.3 \%$ is hydrolyzed very fast, the less accessible pool comprises $28.8 \pm 0.5 \%$ of the total PE, and the residual PE is slowly accessible (Tables II and III). PS can be hydrolyzed also by phospholipase $\mathrm{C}$ but at a very low rate which did not allow the detection of separate pools. That all of the phospholipids can be hydrolyzed by phospholipase $\mathrm{C}$ is demonstrated by the $37^{\circ} \mathrm{C}$ incubations. At this temperature $100 \%$ of the PC and PE and more than $90 \%$ of the PS were hydrolyzed by $150 \mathrm{IU}$ of phospholipase $\mathrm{C} / \mathrm{mL}$. 


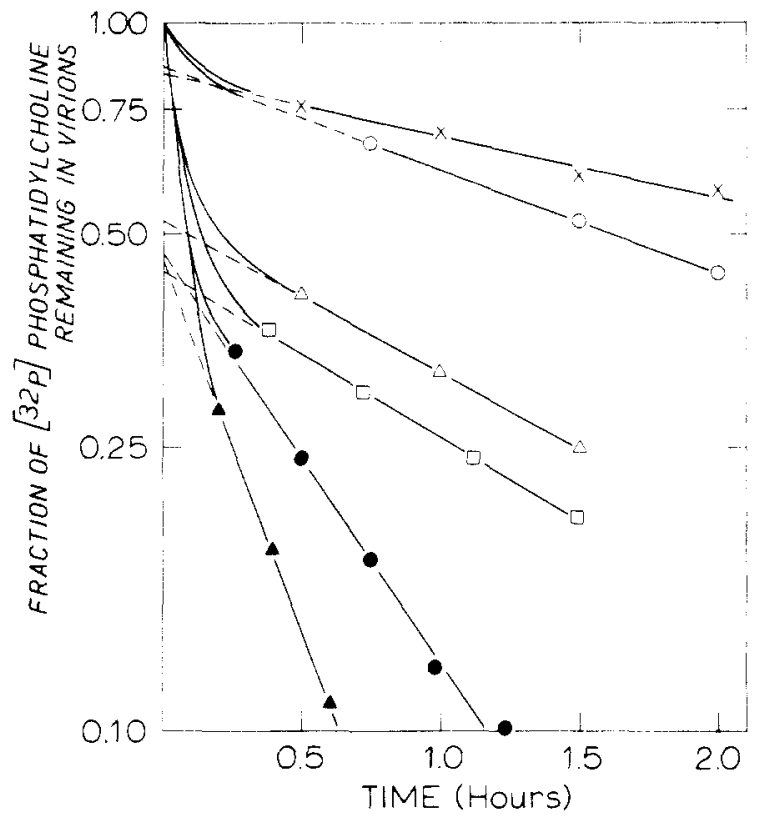

FIGLTRE 2: Semilogarithmic plot of the hydrolysis of [ $\left.{ }^{32} \mathrm{P}\right] \mathrm{PC}$ in [ $\left.{ }^{32} \mathrm{P}\right] \mathrm{SF}$ virus by phospholipase $C$ at $25^{\circ} \mathrm{C}$. $100(X) ; 150(0) ; 200(\Delta$ and ㅁ); $250(\bullet) ; 300 \mathrm{IU} / \mathrm{mL}(\Delta)$. Samples were taken and analyzed as described under Materials and Methods. All symbols represent the mean of two independent determinations and are expressed as the fraction of total viral $\left[{ }^{32} \mathrm{P}\right] \mathrm{PC}$ at $t=0 \mathrm{~h}$.

Sphingomyelin Hydrolysis. $\left[{ }^{32} \mathrm{P}\right] \mathrm{SF}$ virus was incubated with $25-50 \mathrm{IU} / \mathrm{mL}$ sphingomyelinase at 20,25 , and $37^{\circ} \mathrm{C}$, and also in this case extrapolation of the data in semilogarithmic plots to $t=0 \mathrm{~h}$ showed three pools. At low enzyme concentrations of $25-30 \mathrm{IU} / \mathrm{mL}$ and $20^{\circ} \mathrm{C}, 11.0 \pm 3.2 \%$ of the total SM was hydrolyzed at a fast rate (Table II), and at higher enzyme concentrations of $30-50 \mathrm{IU} / \mathrm{mL}$ and $25^{\circ} \mathrm{C}$, $39.7 \pm 9.4 \%$ was degraded as a less accessible pool (Table III). The residual SM could only be hydrolyzed at a much lower rate. The curves had properties equal to those of $\mathrm{PC}$ hydrolysis by phospholipase C. At $37^{\circ} \mathrm{C} 100 \%$ of the SM was degraded by $30 \mathrm{IU} / \mathrm{mL}$ sphingomyelinase.

Hydrolysis of Phospholipids by Phospholipase $A_{2}$. Incubation of $\left[{ }^{32} \mathrm{P}\right] \mathrm{SF}$ virus with phospholipase $\mathrm{A}_{2}$ as described under Materials and Methods yielded results similar to those of phospholipase C. For PC and PE readily accessible pools were determined of $11.3 \pm 5.4$ and $15.4 \pm 7.9 \%$, respectively (Table II). In one experiment, with a higher concentration of phospholipase $\mathrm{A}_{2}\left(200 \mathrm{IU} / \mathrm{mL}, 20^{\circ} \mathrm{C}\right)$, the size of the less accessible pool was determined to be $57 \%$ of the $\mathrm{PC}$ and $20 \%$ of the PE (Table III). That all PC and PE are substrates for phospholipase $A_{2}$ was shown in an incubation of virus with 200 IU of phospholipase $A_{2}$ at $37^{\circ} \mathrm{C}$, in which experiment $96 \%$ of the PC and 94\% of the PE were hydrolyzed within $1 \mathrm{~h}$.

Because in SF virus $70 \%$ of the PE consists of alkenyl-acyl and alkyl-acyl forms (Laine et al., 1972) and ether bonds cannot be hydrolyzed by phospholipase $\mathrm{A}_{2}$, complete hydrolysis of the PE implicates that all ether bonds occur at the C-1 position of the PE.

From extrapolation of the hydrolysis curves for PS, separate pools could never be detected, which, as in the case of phospholipase $\mathrm{C}$, is probably due to the fact that PS hydrolysis was too slow compared to hydrolysis of PC and PE $(2-3 \times$ slower as judged from the slopes of the semilogarithmic plot of the hydrolysis by $200 \mathrm{IU} / \mathrm{mL}$ at $37^{\circ} \mathrm{C} ; 70 \%$ of the PS was hydrolyzed after $1 \mathrm{~h}$ ).

Transfer of Phospholipids from Virions to Vesicles. When $\left[{ }^{32} \mathrm{P}\right] \mathrm{SF}$ virus was incubated with vesicles and phospholipid universal transfer protein, all phospholipid classes appeared

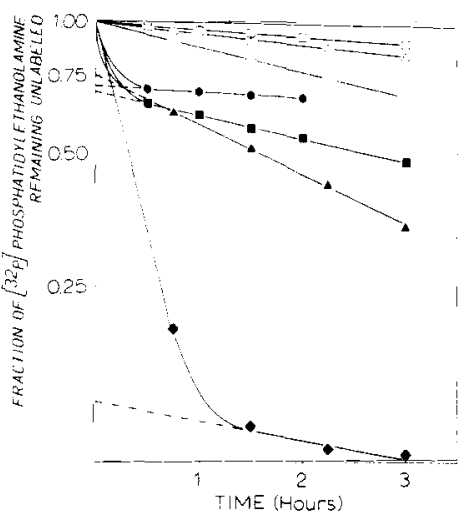

FIGURE 3: Semilogarithmic plot of the labeling of PE (closed symbols) and PS (open symbols) by TNBS. [ $\left.{ }^{32} \mathrm{P}\right] \mathrm{SF}$ virus was incubated in $10 \mathrm{mM}$ TNBS $(O$ and $\bullet), 20 \mathrm{mM}$ TNBS ( $\square$ and $\square$ ), $30 \mathrm{mM}$ TNBS ( $\Delta$ and $\Delta$ ) at $20^{\circ} \mathrm{C}$, or $20 \mathrm{mM}$ TNBS at $25^{\circ} \mathrm{C}(\diamond$ and $\bullet$ ). Samples were taken and analyzed as described under Materials and Methods. All symbols represent the mean of two independent determinations and are expressed as the fraction of total viral $\left[{ }^{32} \mathrm{P}\right] \mathrm{PE}$ and $\left[{ }^{32} \mathrm{P}\right] \mathrm{PS}$ at $t=0$. Identical results were obtained in six ( $O$ and $O$ ), two ( $\square$ and $\square$ ), two ( $\Delta$ and $\Delta)$, and three $(\diamond$ and $\diamond)$ independent experiments.

to be transferred to the vesicles. The rate of transfer for the individual phospholipid classes was dependent not only on the concentrations of transfer protein, virus, and vesicles but also on the phospholipid composition of the vesicles. From extrapolation of the semilogarithmic plots to $t=0 \mathrm{~h}$, however, a readily accessible phospholipid pool was defined, which was not dependent on the vesicle composition: $9.9 \pm 2.5 \%$ of the PC, $10.0 \pm 3.3 \%$ of the SM, $7.0 \pm 0 \%$ of the PE, and $8.5 \pm$ $2.1 \%$ of the PS were readily available for transfer (Table II). So in contrast to the other techniques, the universal transfer protein showed that also part of the PS resides in a readily accessible pool.

Labeling of Amino Phospholipids by TNBS. Incubation of $\left.{ }^{32} \mathrm{P}\right] \mathrm{SF}$ virus with $10-30 \mathrm{mM}$ TNBS at $20^{\circ} \mathrm{C}$ resulted in labeling of $30.9 \pm 6.8 \%$ of the total PE (Table III). The remaining PE was also labeled but at a much lower rate, which was dependent on TNBS concentration. PS was always labeled as one pool (Figure 3). After incubation at $37^{\circ} \mathrm{C}$ with $10 \mathrm{mM}$ TNBS, $100 \%$ of the PE and $50 \%$ of the PS were labeled, but equilibrium for the PS was not yet reached as was seen from the semilogarithmic plot. When virus was incubated with 20-40 mM TNBS at $25^{\circ} \mathrm{C}$, the semilogarithmic plot of the remaining PE against time (Figure 3 ) showed a second breakpoint at $88.7 \pm 2.1 \%(n=3)$.

Characterization of the Readily Accessible Phospholipid Pool in Unlabeled Virions. To see if the readily accessible phospholipid pool in labeled virus preparations was due to, e.g., the low amount of virus in these preparations $(0.7 \mathrm{mg}$ of protein $/ \mathrm{mL}$ compared to $9.6 \mathrm{mg}$ of protein $/ \mathrm{mL}$ in unlabeled virus preparations, unlabeled SF virus $(300 \mathrm{nmol}$ of phospholipid phosphorus was incubated with $150 \mathrm{IU} / \mathrm{mL}$ phospholipase $\mathrm{A}_{2}$ or $50 \mathrm{IU} / \mathrm{mL}$ of sphingomyelinase at $15^{\circ} \mathrm{C}$, and hydrolysis of the phospholipids was followed during $1 \mathrm{~h}$ by taking samples every $10 \mathrm{~min}$. By these enzymes readily accessible pools were defined for PC, SM, and PE of $6.5 \pm 0.5$, $12.1 \pm 3.0$, and $10.6 \pm 2.5 \%$, respectively (Table II) while due to slow hydrolysis again no separate PS pools could be detected. Furthermore unlabeled SF virus $(300 \mathrm{nmol}$ of phospholipid phosphorus) was incubated with $\left[{ }^{14} \mathrm{C}\right] \mathrm{PC}$-containing vesicles (50 nmol of $\mathrm{PC}, 1 \mu \mathrm{Ci} / \mu \mathrm{mol}\left[{ }^{14} \mathrm{C}\right] \mathrm{PC}$, and a trace of $\left[{ }^{3} \mathrm{H}\right]$ cholesteryl oleate as a nonexchangeable marker) and exchange protein $(30 \mu \mathrm{g} / \mathrm{mL})$ in a total volume of $1.5 \mathrm{~mL}$ at $37^{\circ} \mathrm{C}$. After 1,2 , and $3 \mathrm{~h}$, virus and vesicles were separated and the virus pellet was analyzed as described under Materials 
Table IV: Accessibility of SF Virus Ribonucleic Acid to Ribonuclease ${ }^{a}$

\begin{tabular}{|c|c|}
\hline & $\begin{array}{c}\% \text { accessible } \\
\text { RNA }^{b}\end{array}$ \\
\hline $\begin{array}{l}\text { Triton X-100 } \\
\text { control minus ribonuclease } \\
\text { control plus ribonuclease } \\
\text { phospholipase } \mathrm{A}_{2} \\
\quad\left(100 \mathrm{IU} / \mathrm{mL} ; 10 \mathrm{mM} \mathrm{Ca}^{2+}, 0.25 \mathrm{mM} \mathrm{Mg}^{2+}\right)^{c} \\
\text { phospholipase C } \\
\quad\left(100 \mathrm{IU} / \mathrm{mL} ; 5 \mathrm{mM} \mathrm{Ca}{ }^{2+}, 0.25 \mathrm{mM} \mathrm{Mg}{ }^{2+}\right)^{d} \\
\text { sphingomyelinase }(25 \mathrm{IU} / \mathrm{mL} ; 10 \mathrm{mM} \mathrm{Ca})^{d+} \\
\text { TNBS }(10 \mathrm{mM})^{d}\end{array}$ & $\begin{array}{l}100 \\
<1 \\
6.1 \pm 2.8(5) \\
11.4 \pm 4.3(2) \\
8.6 \pm 1.5(4)^{e}\end{array}$ \\
\hline $\begin{array}{l}\text { a }\left[{ }^{3} \mathrm{H}\right] \text { Uridine-labeled SF virus was incubated } \\
\mathrm{h} \text { at } 37{ }^{\circ} \mathrm{C} \text { whereupon accessibility of viral RN } \\
\text { was tested as described under Materials and M } \\
\text { bers are normalized to the amount of acid-solv } \\
\text { in the case of detergent-disrupted virus. They } \\
\text { percentages and are followed by the standard } \\
\text { number of determinations in paren theses. } \\
\text { was followed during } 2 \mathrm{~h} \text { at } 20^{\circ} \mathrm{C} \text { and extrapol } \\
\text { this result. Lysis remained fairly constant du } \\
\text { These mixtures were incubated for } 1 \mathrm{~h} \text { at } 20 \\
\text { was corrected for the observation that only } 75 \\
\text { made acid soluble, when } 1 \% \text { Triton X-100 was } \\
\text { incubation. After all other incubations this w }\end{array}$ & $\begin{array}{l}\text { N buffer for } 1 \\
\text { ribonuclease } \\
\text { s. } b \text { All num- } \\
\text { H label found } \\
\text { esent mean } \\
\text { ion and the } \\
n \text { this reaction } \\
\text { o } t=0 \text { to yield } \\
\text { he incubation. } \\
e \text { This figure } \\
{ }^{3} \mathrm{H} \text { label was } \\
\mathrm{d} \text { after the } \\
0 \%\end{array}$ \\
\hline
\end{tabular}

and Methods. Redistribution of $\left[{ }^{14} \mathrm{C}\right] \mathrm{PC}$ was studied during $3 \mathrm{~h}$, and from the $\mathrm{dpm}$ in the virus at different times and the pool size of exchangeable vesicle $\mathrm{PC}$, the readily exchangeable $\mathrm{PC}$ in the virus could be calculated and appeared to be $12.5 \%$ (Table II).

Control of Lysis. A possible explanation for the presence of a small phospholipid pool in the virus preparations which is readily accessible for all techniques could be the presence of lysed virions. For investigation of this possibility, $\left[{ }^{3} \mathrm{H}\right]$ uridine-labeled SF virus, which had been stored at $-80^{\circ} \mathrm{C}$, was incubated under various conditions (Table IV) and concomitant lysis was determined as described under Materials and Methods. Lysis was defined to be $100 \%$ in virus incubated for $1 \mathrm{~h}$ at $37^{\circ} \mathrm{C}$ in $1 \%$ Triton $\mathrm{X}-100$. In virus incubated for $1 \mathrm{~h}$ at $37^{\circ} \mathrm{C}$ in the absence of ribonuclease, less than $1 \%$ of the ${ }^{3} \mathrm{H}$ label was acid soluble, but when the incubation was done in the presence of ribonuclease $6.1 \pm 2.8 \%$ of the ${ }^{3} \mathrm{H}$ label was rendered acid soluble (Table IV). The incubation conditions which were most likely to cause lysis were also tested. Phospholipase $\mathrm{A}_{2}$, sphingomyelinase, and TNBS slightly enhanced lysis. Phospholipase $C$ in some way seemed to interfere with the RNA digestion for when $1 \%$ Triton was added after the phospholipase reaction was stopped, only $75 \%$ of the RNA could be degraded by ribonuclease, whereas after the other reactions $100 \%$ was degradable. The amount of lysed particles (Table IV) appeared to be in the same range as the size of the readily accessible phospholipid pools.

\section{Discussion}

About $10 \%$ of the total phospholipid content of Semliki Forest virus preparations is readily accessible for exchange proteins and phospholipases under mild circumstances (Table II). The fact that an equal percentage of the different phospholipid classes is present in this fraction and the observation that in these preparations $10 \%$ of the RNA is also accessible to ribonuclease (Table IV) imply that this readily accessible pool of phospholipid is present in lysed virions. As none of the PC was found to be readily exchangeable in fresh virus preparations which had not been frozen before use (data not shown), freezing and thawing appears to be the main cause of the observed lysis.
Besides the readily accessible phospholipids, two additional phospholipid pools were defined by the different techniques (Table III). In analogy to experiments with phospholipid exchange proteins (Rothman \& Dawidowicz, 1975; Bloj \& Zilversmit, 1976), phospholipases (Verkleij et al., 1973; Demant et al., 1979), and amino group labeling reagents (Bretscher, 1972), the accessible pool represents the phospholipids in the outer bilayer leaflet of the viral membrane, whereas the phospholipids that were not, or much less, accessible are located in the inner monolayer.

Of the PC 54\% was found to be accessible for the PC. specific exchange protein. This accessibility was only slightly enhanced up to $59 \%$ by removal of the spikes, which excludes the possibility that the inaccessible PC is present in the outer monolayer, shielded by the glycoproteins. The limited increase in the amount of accessible PC could be due to an increase in the number of lysed virions. The latter phenomenon can also be responsible for the observation that PC exchange did not completely stop when the plateau was reached. From the slope in the second part of the curve (Figure 1), it was calculated that the remaining PC became available for exchange with a half-time of $24 \pm 10 \mathrm{~h}(n=6)$. An alternative explanation is offered by the occurrence of a slow transbilayer movement of the PC. From similar exchange experiments, it was concluded that such a transbilayer movement occurs with half-time values of $7-11 \mathrm{~h}$ in vesicular stomatitis virus (Shaw et al., 1979), $88 \mathrm{~h}$ in plasma membrane derived phagolysosomes (Sandra \& Pagano, 1978), and 10 days in influenza virus (Lenard \& Rothman, 1976).

Removal of the spikes not only increased the total amount of accessible PC but also increased the rate of exchange considerably. Much less exchange protein was required to stimulate exchange in spikeless particles compared with intact virions. The tight packing of the spike proteins (von Bonsdorff \& Harrison, 1978) and the presence of sialic acid in the spikes (Laine et al., 1973) may be the responsible factors. Also, the packing of the phospholipid molecules in the intact virus may be unfavorable [cf. van Meer et al. (1980)], and finally the phospholipids in the intact virus may be shielded by the adsorption of vesicles to the spikes, especially when the vesicles contain cholesterol (Shaw et al., 1979; Mooney et al., 1975).

Hydrolysis of PC and PE by phospholipase $\mathrm{C}$ showed similar biphasic kinetics as were observed with the exchange protein. By use of various enzyme concentrations, the same pools could be defined, $53 \%$ for PC and $28 \%$ for PE (Table III). The observed differences in PC and PE hydrolysis cannot be ascribed to differences in substrate specificity of the phospholipase C (Roelofsen \& Schatzmann, 1977), and therefore these values represent the amounts of $P C$ and $P E$ which are present in the outer layer. On the other hand, PS is hydrolyzed 2-3 times slower than PC and PE by this enzyme (Roelofsen \& Schatzmann, 1977; Roberts et al., 1978) and could not be localized this way.

The sizes of the various pools of phospholipid were derived from a kinetic analysis of the hydrolysis patterns (Demant et al., 1979) and not from direct measurements of an equilibrium situation as used in other studies (Patzer et al., 1978a; Tsai \& Lenard, 1975). In the latter studies virions were incubated with phospholipase $\mathrm{C}$ under mild conditions, and an apparent equilibrium was reached when $\sim 50 \%$ of the phospholipids had been hydrolyzed, without lysis of the virus. Such an approach, however, neglects the possibility that phospholipase $\mathrm{C}$ can induce rearrangements of phospholipids in the bilayer, including transbilayer movements of phospholipids from the inner to the outer layer. That such a process, possibly en- 
Table V: Phospholipid Asymmetry in Plasma Membrane Derived Membrane Structures ${ }^{a}$

\begin{tabular}{|c|c|c|c|c|c|c|}
\hline membrane system & cells & method & $\mathrm{PC}$ & SM & PS & PE \\
\hline Semliki Forest virus ${ }^{b}$ & BHK-21 & $\begin{array}{l}\text { exchange protein } \\
\text { TNBS }\end{array}$ & $52(29)$ & $(24)$ & $(17)$ & $\begin{array}{c}(25) \\
23\end{array}$ \\
\hline vesicular stomatitis virus ${ }^{c}$ & BHK-21 & $\begin{array}{l}\text { phospholipases } \mathrm{C}, \mathrm{A}_{2} \\
\text { TNBS }\end{array}$ & $\begin{array}{c}51 \\
(29)\end{array}$ & $\begin{array}{c}33 \\
(21)\end{array}$ & (10) & $\begin{array}{l}21 \\
36(37)\end{array}$ \\
\hline vesicular stomatitis virus ${ }^{d}$ & BHK-21 & TNBS & (24) & (24) & (18) & $38-47(31)$ \\
\hline vesicular stomatitis virus ${ }^{e}$ & BHK-21 & exchange protein & $58-69$ & & & \\
\hline influenza virus $f$ & MDBK & $\begin{array}{l}\text { phospholipase } \mathrm{C} \\
\text { exchange proteins }\end{array}$ & $\begin{array}{l}34-45(12) \\
43-48\end{array}$ & $\begin{array}{l}23(31) \\
15\end{array}$ & $\begin{array}{l}23-25(16) \\
14\end{array}$ & $28-30(38)$ \\
\hline phagolysosomes ${ }^{g}$ & mouse LM & $\begin{array}{l}\text { exchange proteins } \\
\text { TNBS }\end{array}$ & $48(40)$ & (13) & (12) & $\begin{array}{l}(35) \\
24-30\end{array}$ \\
\hline
\end{tabular}

${ }^{a}$ The numbers are given as the percentage of each individual phospholipid class being present in the outer membrane leaflet and are followed by the phospholipid composition of the studied membrane in parentheses given as the percent of total phospholipid. $b$ This report; the figures were corrected for lysed virions. ${ }^{c}$ Fong et al. (1976). $d$ Patzer et al. (1978a). $e$ Shaw et al. (1979). $f$ Rothman et al. (1976). gandra \& Pagano (1978).

hanced by a rapid transbilayer movement of the diglycerides (Allan et al., 1978), does occur is indicated by a comparison of the hydrolysis patterns (Figure 2) with the data from exchange studies (Figure 1) and TNBS labeling. Whereas hydrolysis continues, the extents of exchange and TNBS labeling reach a true plateau as can be expected because the degree of membrane perturbation induced by the last two approaches is less dramatic than during diglyceride formation. The data presented here emphasize once more that localization studies based on phospholipase $C$ treatment can be unreliable, especially in case of an equilibrium approach [cf. Sundler et al. (1978)], and that independent techniques are required to confirm the results obtained with the enzyme. Consequently, the exchange approach was used to confirm localization data obtained for PC and chemical labeling for PE. Rothman et al. (1976) were able to confirm results from an equilibrium approach of phospholipase $C$ with exchange proteins, but the membrane of this influenza virus was exceptional in that the outer monolayer appeared to contain a very high amount of glycolipids, which may prevent reorganization of the phospholipids (Sundler et al., 1978).

Chemical labeling of the PE yielded similar results as the phospholipases, locating $31 \%$ in the outer monolayer (Table III). Clearly the PE in lysed virions was not labeled more readily, because it could not be distinguished as a separate pool. That only a small fraction of the PE is located on the outside of SF virus, when grown in BHK-21 cells, has also been reported by Gahmberg et al. (1972) using the amino group labeling reagent formyl methionyl sulfone methyl phosphate.

The control experiment in which TNBS was used under penetrating conditions showed that indeed all of the PE was labeled but that a small part of the total PE pool was labeled at a very low rate. The latter effect can be explained by the observation of Bishop et al. (1979) that steric hindrance of the bulky trinitrophenyl groups inhibited complete labeling of the PE. Also, the slow rate of labeling of PS can be explained by the former studies. The negative charge of this phospholipid inhibits the coupling.

From the results of the different techniques (Table III), an overall picture of the phospholipid distribution over the bilayer of SF virus was obtained (Table V). PC appeared to be about equally distributed, whereas $\mathrm{PE}$ was enriched in the inner monolayer. Also, SM was enriched in the inner monolayer, although only one technique was available to localize this phospholipid. PS could not be localized. Altogether $30 \%$ of the viral phospholipids can be assigned to the outer monolayer, $50 \%$ can be assigned to the inner monolayer, and 20\% (PS and some minor phospholipids) could not be located.

Apart from phospholipids ( $48 \mathrm{~mol} \%$ of the total lipid), SF virus grown in BHK-21 cells contains $4 \mathrm{~mol} \%$ glycolipids, which are all located externally (Gahmberg \& Hakomori, 1976), and $48 \mathrm{~mol} \%$ of cholesterol (Renkonen et al., 1971; Laine et al., 1973). Based on the size of the SF virus particle [516- $\AA$ diameter (Helenius et al., 1977)], the number of phospholipid-cholesterol pairs per virion [16000-17000 (Laine et al., 1973)], and the surface area occupied by the transmembrane protein [ $<10 \%$ (Harrison et al., 1974)], the surface area per phospholipid-cholesterol pair can be calculated, in the case of an equal distribution of the lipids over both layers of the membrane. This surface area turned out to be $80 \AA^{2}$, being an absolute minimum for a phospholipid-cholesterol pair (Levine \& Wilkins, 1971). This minimal value excludes the possibility that the lipid is not distributed equally over the two monolayers. As a consequence PS has to be assigned completely to the outer monolayer. Only if relatively more cholesterol is present in the outer monolayer can part of the PS reside in the inner monolayer [cf. Gahmberg et al. (1972)].

The enveloped viruses, listed in Table V, obtain their lipid bilayer from the plasma membrane of the host cell during the budding process (Acheson \& Tamm, 1967; Nakai \& Howatson, 1968). Data on phospholipid localization in the virus can be extrapolated therefore to the plasma membrane of the host cell. That such an extrapolation is justified is shown by a comparison between the data presented here for SF virus and data obtained for vesicular stomatitis virus (Table V), grown in the same cell line. Although the morphology of both viruses differs markedly (Acheson \& Tamm, 1967; Nakai \& Howatson, 1968), they have a similar phospholipid composition, and also the results of the phospholipid localization studies are similar. It can be concluded, therefore, that the phospholipid distribution in the plasma membrane of BHK-21 cells is as is summarized in Table V. The only restriction to be made here is that the budding process may take place at specialized regions of the host cell plasma membrane, with a phospholipid composition differing from the bulk phospholipid composition. No data are known, however, to illustrate this.

An asymmetrical phospholipid distribution over the plasma membrane has also been reported for MDBK and mouse LM cells by using influenza virus and phagolysosomes as probes, respectively (Table $\mathrm{V}$ ). The reported distributions are very similar to the distribution found for BHK-21 cells. PC is about equally distributed and most $\mathrm{PE}$ is present in the inner membrane leaflet. Moreover, in one study (Rothman et al., 1976) most of the SM was assigned to the inner monolayer, which is similar to our findings on Semliki Forest virus. It is tempting to speculate from these data that an asymmetric phospholipid arrangement is present in those area's of the plasma membrane which are involved in the budding process or in phagocytosis. More data, however, are necessary to determine if phospholipid asymmetry extends over the whole plasma membrane and if 
it is a characteristic feature of plasma membranes of all nucleated mammalian cells.

\section{Acknowledgments}

We are indebted to Hilkka Virta for excellent technical assistance in the growth and purification of the virus. We are indebted to Drs. K. W. A. Wirtz, P. F. H. Franck, G. H. de Haas, B. Roelofsen, and M. Th. Kauerz for their generous donation of exchange proteins and phospholipases.

\section{References}

Acheson, N. H., \& Tamm, I. (1967) Virology 32, 128-143. Allan, D., Thomas, P., \& Michell, R. H. (1978) Nature (London) 276, 289-290.

Bangham, A. D., Standish, M. M., \& Watkins, J. C. (1965) J. Mol. Biol. 13, 238-252.

Bishop, D. G., Bevers, E. M., van Meer, G., Op den Kamp, J. A. F., \& van Deenen, L. L. M. (1979) Biochim. Biophys. Acta 551, 122-128.

Bligh, E. G., \& Dyer, W. J. (1959) Can. J. Biochem. Physiol. 37, 911-917.

Bloj, B., \& Zilversmit, D. B. (1976) Biochemistry 15, 1277-1283.

Bloj, B., \& Zilversmit, D. B. (1977) J. Biol. Chem. 252, 1613-1619.

Bretscher, M. S. (1972) J. Mol. Biol. 71, 523-528.

Broekhuyse, R. M. (1969) Clin. Chim. Acta 23, 457-461.

Colley, C. M., Zwaal, R. F. A., Roelofsen, B., \& van Deenen, L. L. M. (1973) Biochim. Biophys. Acta 307, 74-82.

Demant, E. J. F., Op den Kamp, J. A. F., \& van Deenen, L. L. M. (1979) Eur. J. Biochem. 95, 613-619.

Fong, B. S., \& Brown, J. C. (1978) Biochim. Biophys. Acta 510, 230-241.

Fong, B. S., Hunt, R. C., \& Brown, J. C. (1976) J. Virol. 20, 658-663.

Gahmberg, C. G., \& Hakomori, S. (1976) Biomembranes 8, 131-165.

Gahmberg, C. G., Simons, K., Renkonen, O., \& Kääriäinen, L. (1972) Virology 50, 259-262.

Harrison, S. C., Jack, A., Goodenough, D., \& Sefton, B. M. (1974) J. Supramol. Struct. 2, 486-495.

Helenius, A., Fries, E., \& Kartenbeck, J. (1977) J. Cell Biol. $75,866-880$.

Kääriäinen, L., Simons, K., \& von Bonsdorff, C.-H. (1969) Ann. Med. Exp. Biol. Fenn. 47, 235-248.

Kamp, H. H., \& Wirtz, K. W. A. (1974) Methods Enzymol. $32,140-146$.

Laine, R., Kettunen, M.-L., Gahmberg, C. G., Kääriäinen, L., \& Renkonen, O. (1972) J. Virol. 10, 433-438.

Laine, R., Söderlund, H., \& Renkonen, O. (1973) Intervirology $1,110-118$.

Lenard, J., \& Rothman, J. E. (1976) Proc. Natl. Acad. Sci. U.S.A. 73, 391-395.
Levine, Y. K., \& Wilkins, M. H. F. (1971) Nature (London), New Biol. 230, 69-76.

Lowry, O. H., Rosebrough, N. J., Farr, A. L., \& Randall, R. J. (1951) J. Biol. Chem. 193, 265-275.

Mooney, J. J., Dalrymple, J. M., Alving, C. R., \& Russell, P. K. (1975) J. Virol. 15, 225-231.

Nakai, T., \& Howatson, A. F. (1968) Virology 35, 268-281.

Nieuwenhuizen, W., Kunze, H., \& de Haas, G. H. (1974) Methods Enzymol. 32B, 147-154.

Op den Kamp, J. A. F. (1979) Annu. Rev. Biochem. 48, 47-71.

Patzer, E. J., Moore, N. F., Barenholz, Y., Shaw, J. M., \& Wagner, R. R. (1978a) J. Biol. Chem. 253, 4544-4550.

Patzer, E. J., Shaw, J. M., Moore, N. F., Thompson, T. E., \& Wagner, R. R. (1978b) Biochemistry 17, 4192-4200.

Patzer, E. J., Wagner, R. R., \& Dubovi, E. J. (1979) CRC Crit. Rev. Biochem. 6, 165-217.

Renkonen, O., Kääriäinen, L., Simons, K., \& Gahmberg, C. G. (1971) Virology 46, 318-326.

Renkonen, O., Kääriäinen, L., Petterson, R., \& Oker-Blom, N. (1972) Virology 50, 899-901.

Richardson, C. D., \& Vance, D. E. (1976) J. Biol. Chem. 251, 5544-5550.

Roberts, M. F., Otnaess, A.-B., Kensil, C. A., \& Dennis, E. A. (1978) J. Biol. Chem. 253, 1252-1257.

Roelofsen, B., \& Schatzmann, H. J. (1977) Biochim. Biophys. Acta 464, 17-36.

Rothman, J. E., \& Dawidowicz, E. A. (1975) Biochemistry 14, 2809-2816.

Rothman, J. E., Tsai, D. K., Dawidowicz, E. A., \& Lenard, J. (1976) Biochemistry 15, 2361-2370.

Rouser, G., Fleischer, S., \& Yamamoto, A. (1970) Lipids 5, 494-496.

Sandra, A., \& Pagano, R. E. (1978) Biochemistry 17, 332-338.

Shaw, J. M., Moore, N. F., Patzer, E. J., Correa-Freire, M. C., Wagner, R. R., \& Thompson, T. E. (1979) Biochemistry 18, 538-543.

Sundler, R., Alberts, A. W., \& Vagelos, P. R. (1978) J. Biol. Chem. 253, 5299-5304.

Tsai, K.-H., \& Lenard, J. (1975) Nature (London) 253, 554-555.

Utermann, G., \& Simons, K. (1974) J. Mol. Biol. 85, 569-587.

van Meer, G., Poorthuis, B. J. H. M., Wirtz, K. W. A., Op den Kamp, J. A. F., \& van Deenen, L. L. M. (1980) Eur. J. Biochem. 103, 283-288.

Verkleij, A. J., Zwaal, R. F. A., Roelofsen, B., Comfurius, P., Kastelijn, D., \& van Deenen, L. L. M. (1973) Biochim. Biophys. Acta 323, 178-193.

von Bonsdorff, C.-H., \& Harrison, S. C. (1978) J. Virol. 28, 578-583.

Zwaal, R. F. A., Roelofsen, B., Comfurius, P., \& van Deenen, L. L. M. (1971) Biochim. Biophys. Acta 233, 474-479. 